\title{
METAL APPLIQUES IN BRONZE AGE EUROPE - SEARCHING FOR THE MEANING BEHIND TACKS, BUCKLES AND LAMELLAS
}

\author{
B I A N K A N E S S E L
}

\begin{abstract}
Metallic décor is found in many different regions and has sparked a lot of interest, in particular regarding technological questions. Although much has been written about pottery with metal applications, the different techniques and ways of ornamentation in Europe have never been related to each other. Besides, the origin of the custom and potential motivations behind it is barely discussed. The same is true about the relations between distant areas with metal-decorated pottery. This paper discusses the distribution and meaning of different types of metal decoration on ceramic and wooden vessels, with special regard to the 'rivet-like' décor made of round bronze metal sheets. The finds enable us at least to reconstruct certain aspects of this custom. Technical and stylistic analyses point once more to wide-ranging connections between northern Europe and the Carpathian Basin. It seems that the origin of the metal application might lay in northern Europe.
\end{abstract}

Keywords: Carpathian Basin, northern Europe, Iberian Peninsula, Bronze Age, metal appliques.

\section{INTRODUCTION}

The idea of this study arose a few years ago while I was revising stone and metal tools from the Late Bronze Age in the Carpathian Basin. My interest was triggered by a vessel of the urnfield cemetery of Beluša, Slovakia, which is characterized by outstanding protuberances covered with bronze metal sheets (Fig. 3: $\mathrm{m}$ ). While searching for analogies it became clear, that this vessel is part of a pan-European custom.

Metal decorated pottery is differently structured and manufactured in various distant European regions (Fig. 1). In contrast to most other pottery decorations, this décor is not bound to a certain ceramic style, but specific provinces.

I am particularly happy to dedicate this contribution to the jubilee since pottery with metal décor both concerns the knowledge of potters and metalworkers. Both subjects belong to the major interests of Jozef Bátora, who has dedicated his research especially to Bronze Age cultures in Slovakia and their contacts in Europe. His comprehensive work helped the research community to understand cultural connections between wide-ranged phenomena better but also made it possible to study details effectively. The following explanations would like to follow this tradition.

\section{TECHNIQUES AND MATERIALS}

The various techniques of metal application on pottery are tied to different metals (Fig. 2). The ear- liest is the painting of large ornaments with golden particles (auripigment) on polished, dark pottery with brushes. The pigment has a pasty consistency and usually detaches easily from the surface. Material analyses of this auripigment indicate the use of river gold, which consists of a natural gold-silver alloy with low copper content. The particles show irregular, rough shapes and their surfaces lack any indication of smoothing or pressing after their application (Éluère/Raub 1991, 13-15). Although auripigment was extensively used on wall paintings in Egypt and the Near East, the use of the particles as an element of pottery decoration remains very rare. Three vessels from the copper age cemeteries of Varna and Krivodol were decorated with auripigment and a few others are known from a grave of an 18th dynasty official in the necropolis of Thebes West, Egypt (Noll 1991, 199, 200).

A different technique is bound to the Aegean Bronze Age, were pottery vessels were almost entirely covered with thin metal foils (Fig. 3: c, d). They are attached to the pottery surface with different types of organic glue and almost all of them were made of tin (Gillis 1991; 1994; 1997). Experiments regarding the suggested 'tin coating' of Hellenistic vessels have shown that among the tested substances, egg white is most suitable to apply the metal foil on the carrier surface (Éluère/Raub 1991, 13-15).

The application of metal lamellas on parts of the vessel's body is the third method of metal decoration, which is mostly found in Switzerland, eastern France, and south-western Germany. The lamellas are also made of tin and mostly attached to the outer parts of the vessels (Fig. 3: e-g). The ornamentation 


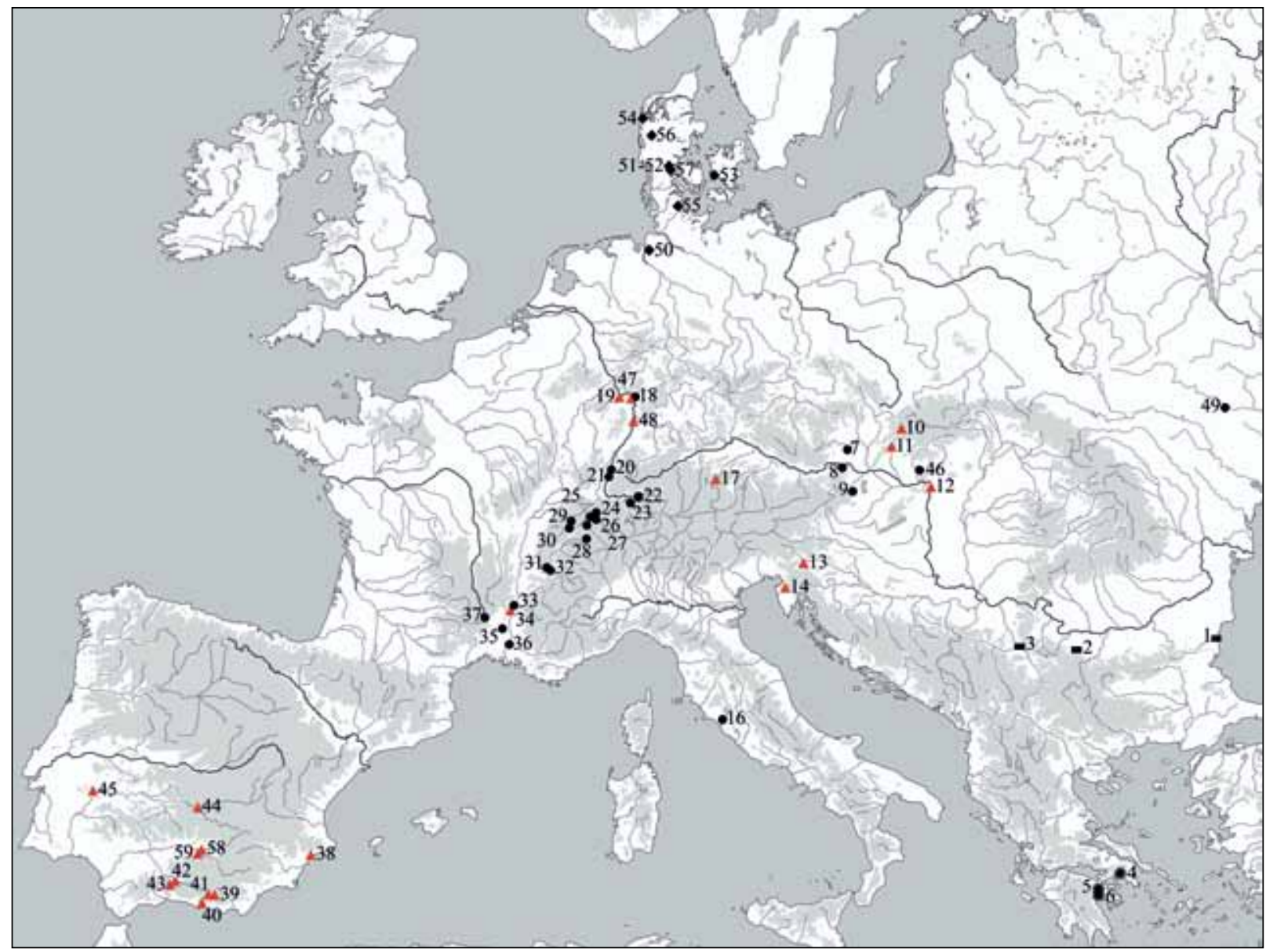

Fig. 1. Distribution of metal decorated pottery from the Copper Age until the late Urnfield period (rectangle - painted metal décor; star - foil cover; dot - lamella décor; triangle - décor of roundish metal sheet; diamond - tacks). 1 - Varna; 2 -Krivodol; 3 - Bubani; 4 - Athen; 5 - Mykene; 6 - Dendra; 7 - Oberavelsbach; 8 - St. Andrä vor dem Hagenthale; 9 - Pitten; 10 - Beluša; 11 - Očkov; 12 - Budapest; 13 - Ljubljana; 14 - Laganiši cave; 15 - Picuge; 16 - Tarquinia; 17 - München-Englschalking; 18 - Trebur; 19 - Bad Kreuznach; 20 - Burkheim am Kaiserstuhl; 21 -Oberrimsingen; 22 - Neftenbach-Steinmöri; 23 -Zürich-Alpenquai; 24 - Lac de Bienne; 25 - Cortaillod; 26 - Mörigen; 27 - Chatillon; 28 - Vuadens; 29 - La Saut; 30 - Doubs; 31 - Conjux; 32 - Grésine; 33 - Grotte Déroc; 34 - Navacelles-Gard; 35 - Foissac-Gard; 36 - Malgoires; 37 - Freyssinel; 38 - Caramoro II; 39 - Cerro de la Encina; 40 - Cerro de la Miel; 41 - Cerro de la los Infantes; 42 - Vega de Santa Lucia; 43 - Mesa de Setefilla; 44 - Cerro de Alarcos; 45 - Cerro de la Muela/La Alcazaba; 46 - Brhlovce; 47 - Nierstein; 48 - Rheingönnheim; 49 - Hordeevka; 50 - Heerstedt; 51 - Store Kongehoj (Vester Vamdrup); 52 - Guldhoj (Vester Vamdrup); 53 - Gryderup; 54 - Flödhoj; 55 - Norby (Rieseby); 56 - Store Hoj (Barde); 57 - Lille Dragshoj (Højrup); 58 - Llanete de los Moros; 59 - Colina de los

Quenados. Not mapped: Knossos, Isopata, Ialysos, finds of the Babino (mnogovalikova) and the Belozerka Culture.

is only attached to the inner surfaces on wide-open vessel types, such as bowls (Fig. 3: h).

The vessel's surfaces are often blackened by graphite, which creates a high contrast between the metal ornaments and the ceramic surfaces. Egg-based glues are again the most probable medium used to attach the lamellas (Cottier-Angel/Duboscq/Harari 1997, 128). Early Iron Age northern and central Italy were centers of tin lamella decoration on dark-toned pottery (Dobiat 1980, 130-140; Laffineur 1974, 30).

In northern Europe, the metal decor was not attached to pottery, but instead created by tacks inserted in wooden surfaces (Fischer U. 1954; Randsborg/Chris- tensen 2006, 128, 129, 133, 135, 137, 139; Stjernquist 1958). They are only found on wooden drinking vessels, which were probably also blackened by fire (Aner/Kersten 1986, 31). These small tacks were usually made of tin, but on some cups additional bronze buckles are applied, so that combined ornaments of silver and gold coloured buckles appear (Fischer U. 1954). Similar arrangements are only known from much younger wooden vessels from Italy (Hencken 1968, 210, fig. 189: 1).

In south-eastern Europe, south-western Germany, and the Iberian Peninsula, small, usually roundish metal foils were used to decorate pottery. 


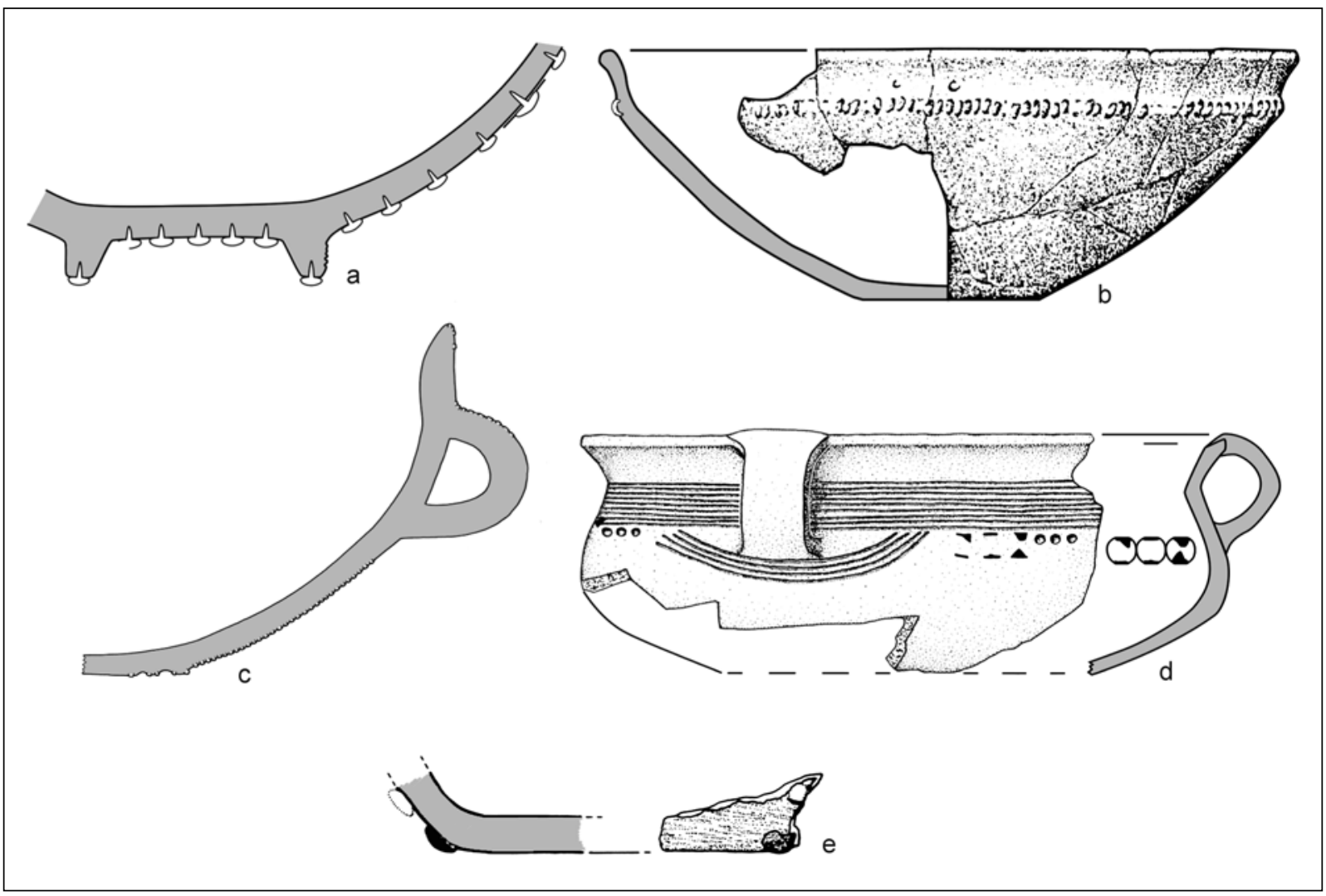

Fig. 2. Techniques of metal application in the Bronze Age. a - riveting (after Rieth 1939-1940); b, d - pressing of sheet metal in the clay surface (after Carrasco/Pastor Muñoz/Pachón Romero 1985, fig. 24; Lochner 1986, pl. 3: 1); c - tack tossing (after Aner/Kersten 1995, pl. 9); d - metal sheet covering clay protuberances (after Lochner 1986, pl. 3: 1); e-Alcazaba (after Garcia Huerta/Rodriguez 2000, fig. 9: 2). Scales vary.

Although often stated, the Bronze Age decorations are not made with actual rivet-like pins stuck in small holes on the surfaces. Instead, several examples such as the vessels from Bad Kreuznach, Germany (Fig. 3: i; Brücken 2010), Oberravelsbach, Austria (Fig. 2: d; Lochner 1986, 302) or Cerro de los Infantes, Spain (Molina 1983) show, that thin metal sheets with small lashes on two or more sites cover a clay protuberance and were stuck into the ceramic surface around it. Another way to attach them was simply to press them in the moist clay before firing the vessel. This is confirmed by a small cup from Laganiši cave, Croatia, where incised circles from the foil attachment foundation are visible (Fig. 4: k; Mihovilić 2008). The buckles are often placed at the widest or most prominent parts of the vessel's body and form the only decoration.

An additional adhesive might have been used to attach the sheets to the protuberances, but as far as I know, no analyses of possible materials have been carried out on vessels from south-eastern Europe or the Iberian Peninsula. All analysed rivet-like pins and sheets to cover protuberances from Europe are made of tin bronze (Lucas Pellicier 1995, 116). Because there is no indication for the use of pure copper or other materials, it can be assumed that all buckle-decorations are made with bronze.

The described application methods build a sharp contrast to the bronze rivets used to decorate helmets and vessels in the Early Iron Age, where real bronze rivets were attached in holes worked in the surfaces of vessels, models of helmets and house urns.

\section{CONTEXTS, TECHNIQUES AND CHRONOLOGY}

In the following, I do not intend to repeat all find circumstances from central Europe. This was done comprehensively many times before (Fischer U. 1954; Fischer C. 1993; Gebhard 1997) and shall only be completed by finds not included in previous compilations. Rather, I will try to connect the techniques and the meaning of the objects with the chronology of the finds.

The oldest of the techniques is the painting with auripigment, which is known from two vessels from burial 4 at the Varna cemetery of the $4^{\text {th }}$ millennium 

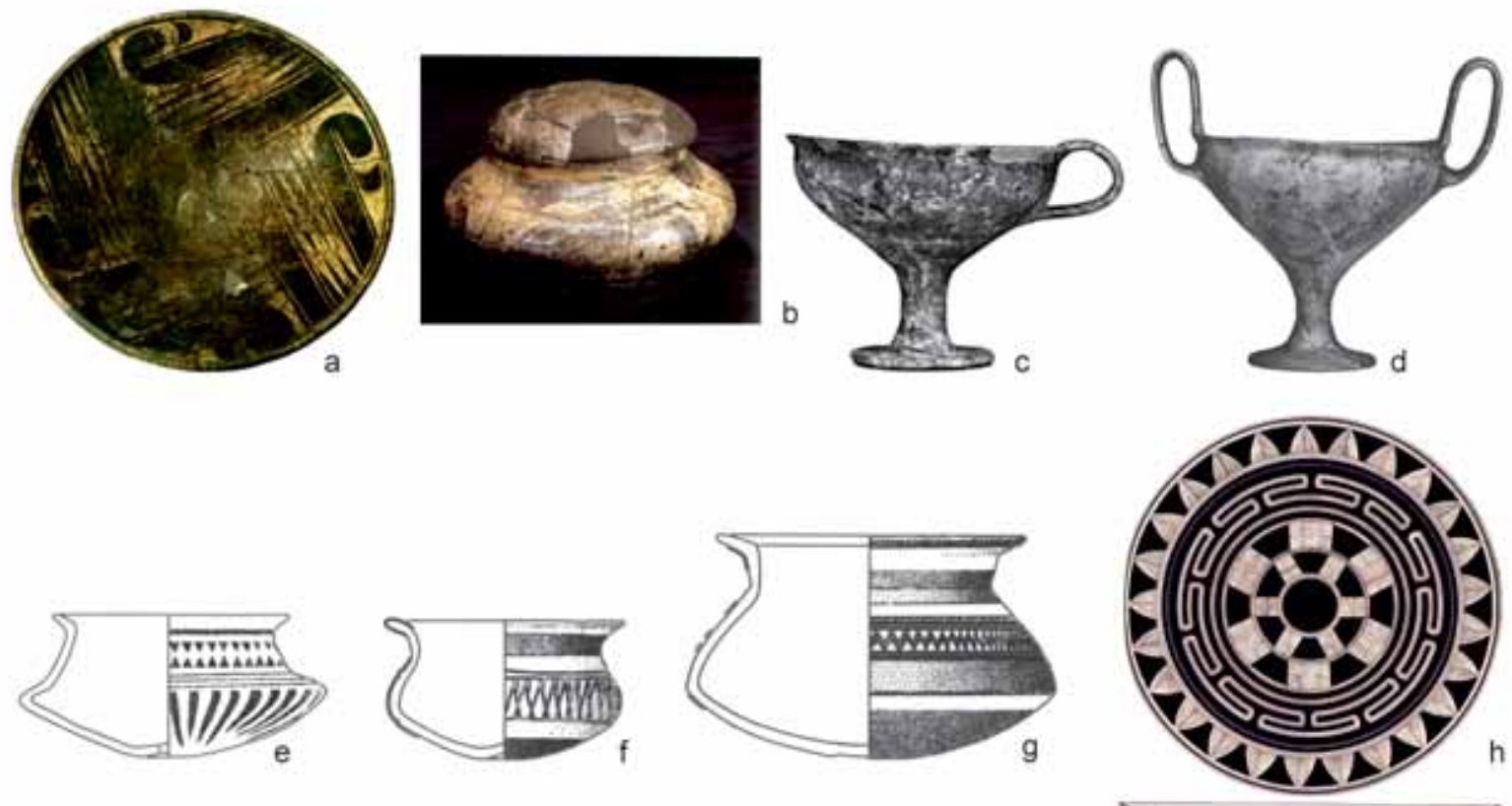

\section{h}
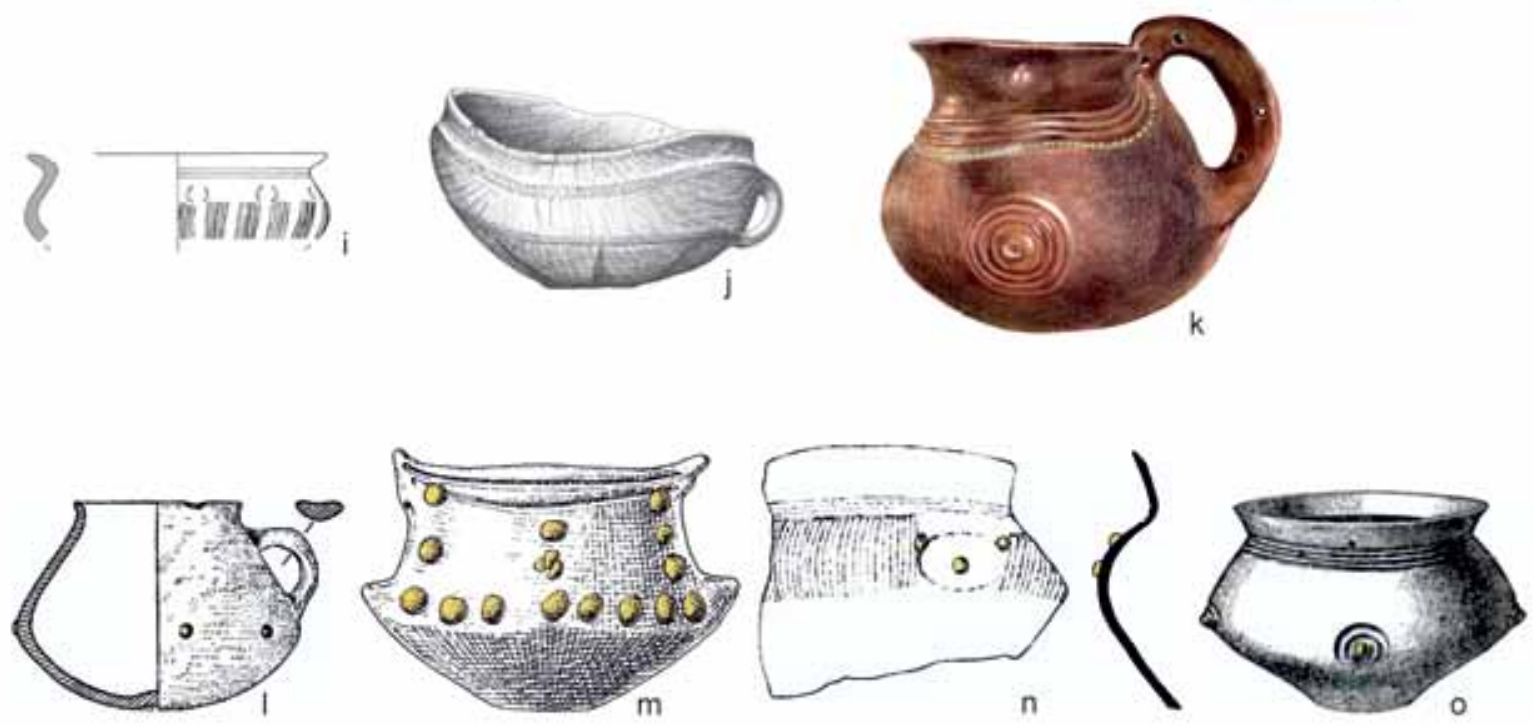

Fig. 3. Metal applications in the Bronze Age. a, b - Varna (after Ivanov 1988, fig. 19); c, d - Dendra (after Pantelidou 1971, fig. 5: 8); e - Canegrate (after Fischer C. 1993, fig. 2: 3-6); f - Neftenbach (after Fischer C. 1993, fig. 2: 3-6); g - Oberrimsingen (after Fischer C. 1993, fig. 2: 3-6); h - Cortaillod (after Stjernquist 1958, fig. 11); i - Bad Kreuznach (after Brücken 2010, fig. 21); j - Vester Vamdrup, Guldhoj (after Aner/Kersten 1986, pl. 17); k - Laganiši cave (after Mihovilić 2008, 17); 1 - Setefilla (after Carrasco/Pastor Muñoz/Pachón Romero 1985, fig. 25: 2); m - Beluša (after Furmánek 1970); n - Navacelles (Gard; after Hugues 1969, fig. 2: 1); o - Nierstein (after Dehn 1942, fig. 53). Scales vary.

BC (Fig. 3: a, b; Ivanov 1988, 189). Two others with similar decoration patterns are known from Krivodol and Bubani Hum (Éluère/Raub 1991, 20).

In the $3^{\text {rd }}$ millennium BC, evidence for metal decoration of pottery is lacking. Although mentioned by W. Noll $(1991,229)$, the existence of a metal-plated vessel from the Cyclades in the middle of the $3^{\text {rd }}$ century BC cannot be verified.
From the beginning of the $2^{\text {nd }}$ millennium BC a few finds of metal application on wooden vessels are known in burials of the Babino (mnogovalikova) culture (Berezanskaja/Kločko 1998, 17; dating: Parzinger 2006, 353).

The first Aegean vessels with attached metal foils date around $1400 \mathrm{BC}$, which is the second phase of the Aegean Late Bronze Age. This is particularly 
interesting because all Nordic tack decorated wooden vessels appear in grave mounds of Period II of the Nordic Bronze Age, which stretches from 1500$1300 \mathrm{BC}$. For some of these graves, ${ }^{14} \mathrm{C}$-data suggest the last use of the inventory between 1389-1370 BC ${ }^{1}$ (Randsborg/Christensen 2006; Stjernquist 1958, 108). This means, that there is no time difference between the appearances of metal decorating styles in these two regions, which could be used as an indicator for an interdependent development. This is even more unlikely since both regions used completely different ways to attach metal to vessel surfaces, which most probably went along with different meanings.

The application of lamellas appears first in the central European Late Bronze Age in subphase D. Most of the finds come from the western Alps and neighbouring regions, but there is also one example from Grave 3 in Pitten at the fringes of the eastern Alps (Fischer C. 1993; Gebhard 1997). Except for the finds from Switzerland, where lamella decorated pottery is mostly known from the lake settlements (Fig. 3: e-g), the finds are also part of burial inventories. All show the same technique of application and similar materials used. In this period, only two other burials in the Hordeevka cemetery are known to contain wooden vessels with metal applications. In one case the metal décor is made of bronze and attached with small bronze tacks (Berezanskajal Kločko 1998, 38, No. 8, 9). Although manufactured as one sheet, it follows the concept of triangular patterns on two sides, which is typical for later tin lamella decoration.

The other wooden vessel from Hordeevka was found in Kurgan 31 and is the only example of the application of golden metal sheets and bronze tacks in this period. It is also made from a metal sheet, but again has a visual appearance, which fits the concept of the triangular pattern well (Berezanskajal Kločko 1998, 41, No. 3, pl. 57: 3, 4). Similar, but less geometrically formed, are some bronze metal sheets from the Lobojkovka hoard, which also dates to this period (Leskov 1981, 8-12, pl. 3: 53-63).

In the $12^{\text {th }}$ century BC (HA1), to which we also count the small jug from Beluša (although Furmánek dated it to BD-HA), all known metal decorations are made of bronze. At least three different methods of application can be identified: the overlay of clay protuberances with metal sheets at the vessels from Beluša and Laganiši cave, the incrustation with bronze wire in a broken jar from Očkov, Slovakia (Paulík 1962), and the insertion of 'rivet-like' studs at the suction cup from München-Englschalking, Germany. The latter vessel shows comparatively severe damage to its surface where the former me- tal applications were applied (Müller-Karpe 1957, pl. 53: 10). This cannot be attributed to the method of metal application stated by H. Müller-Karpe, nor can it be explained by the corrosion of the metal. Maybe several methods may have been combined.

Some appliques made of figural sheet metal are of a similar date, and found in contexts of the Belozerka culture (Vancugov 1996). There are no roughly contemporary analogies in the study area, nor is there a stylistic similarity between the finds from different regions. Nonetheless, technically similar bronze sheets appear on pottery vessels in Italy roughly 300 years later (Grubinger 1930, 116, fig. 3; Szombathy 1903, 65).

From the $11^{\text {th }}-9^{\text {th }}$ century BC the decoration with bronze buckles and tin lamellas is equally frequent but regionally separated. The bronze buckles are found on the Iberian Peninsula, with one exception from Bad Kreuznach in south-western Germany (Brücken 2010). In contrast, the lamella décor has a wider distribution, but it is concentrated to Switzerland, south-eastern France, and south-western Germany. A few vessels are also known from St. Andrä vor dem Hagenthale, Austria (Eibner 1967, 46), and from Brhlovce in Slovakia (Ožd'áni 1977).

The youngest metal decorated vessels in this study date to the $9^{\text {th }}$ century BC in HB3 period. Although this is not entirely certain for all artefacts, judging from the well-investigated vessels it can be assumed that they are mainly, if not exclusively decorated with metal sheets covering clay protuberances (León Pastor 2002-2003, 42). An interesting regional separation is apparent, where most of the vessels with this decoration come from the south of the Iberian Peninsula, while others were found in the cemetery of Ljubljana, Slovenia in the south-eastern Alpine area. The gap between both regions is only closed by finds younger than $850 \mathrm{BC}$, when the 'rivet-like' studs appear as a regional preference in northern and central Italy. These real metal rivets are known from Tarquinia, where they begin to occur in Villanova I A contexts. These bronze rivets applied to different clay models are exclusively linked to funerary contexts. Burials, which contain wooden or textile inventory decorated with bronze studs belong almost entirely to the Early Iron Age and are therefore not addressed in this study (e. g. Tomba del Guerro: Hencken 1968, 28, fig. 189 and other burials of the Monterrozzi cemetery: Hencken 1968, 542).

Most of the finds of the Latest Bronze Age in Europe come from settlements, which is a clear difference to earlier subphases. A combination of bronze buckles and tin lamellas to decorate pottery was only

1 Gryderup, Guldhoj, Lille Dragshoj 
found in the settlement of Alarcos (Garcia Huertal Rodriguez 2000, 56, fig. 9). However, four vessels from Ljubljana were found in burials (Dular 1982).

Other vessels of the Late Urnfield period, such as an urn of Singen am Hohentwiel, might originally have been decorated with metallic appliques and/ or actual bronze rivets (Kossack 1995, 39, fig. 35: 1), which is indicated by small holes at their widest part.

\section{NATURE OF CONTEXTS}

Most of the metal decorated pottery was found in burial contexts. The inventories they belong to are often opulent and contain elaborated objects. The wooden vessels, which are only known from burial mounds with enormously costly oak coffin graves, and the kurgans from Hordeevka equipped with a large number of amber beads, bronzes and golden jewellery (Berezanskaja/Kločko 1998, 38, 41).

Burials, which contain pottery with metallic applications follow a similar pattern, which is best described by the burial inventory from Bad Kreuznach, where a woman was buried with several vessels, a full set of bronze costume components, several amber beads and a unique bronze belt in a wooden chamber under a stone covered mound (Brücken 2010; Zipp 2010). Comparable burials are sparsely distributed in the Urnfield cultures and are without comparisons in south-western Germany.

However, almost all vessels with metal appliques represent common forms in their regions. In southern and central France and Germany vessels with bronze buckles belong either to the so-called buckle pottery or to the classical Urnfield culture. The same can be said about the southern Alpine region and the northern Carpathian basin. Only the miniature model of an urn with tin lamella decor found in Chissay-en-Touraine is of an unusual type in the region and has no local analogies (Hugues 1969, 209).

\section{MEANING}

Considering the techniques it is possible to identify three regions of metal decoration on pottery (Fig. 1). In the Aegean, a flat surface cover of metal foil was used to decorate ceramics. Most researchers agree that the intention was to imitate metal vessels. The latter are in the region characterized by a shiny surface and made of precious metals, such as silver, electrum or stone. Tin was probably used to manufacture the foils because it does not corrode quickly and kept a shiny polish appearance.
In eastern France, south-west Germany, Switzerland, and Italy metal lamellas form distinctive ornaments, which embellish the vessel but do not cover its entire surface. The intention was not to create a shiny appearance but to ensure high visibility of the silver-coloured ornament on a dark surface. It could be argued that the black surface was intended to imitate corroded silver vessels and has a specific meaning as well. Although an intriguing thought, the form of the vessels seems to oppose. Almost none of the metal decorated pottery has analogies in local metal vessels, which is mostly due to the fact, that cups and other drinking vessels are barely decorated with metal lamellas or buckles.

Bronze buckles are the only decorative elements that appear in both western and south-eastern Europe. On the Iberian Peninsula, they occur on pottery in burials and settlements. The southern and central part of Spain, where most of the vessels were found, is characterized by a hilly landscape, where different valleys lie next to each other. Therefore, the vessels with buckle decor have been interpreted as markers of population group identities in certain valleys (Torres Ortiz 2001, 278). Although a reasonable explanation, this is without doubt a regional phenomenon and certainly not applicable to other areas.

But there are also differences in the ways the buckle décor was carried out in the Carpathian Basin and the south-eastern Alps. The buckle-decor of the small jug from Beluša is characterized by large, outstanding clay buckles covered with bronze foil. V. Furmánek and V. Kruta (2002, 125, No. 196) assumed, that the vessel's entire surface was originally covered by bronze foil. But considering the manufacture traditions and analogies in the area, this is unlikely. Although it is not explicitly said, the assumption is probably based on a comparison of the Beluša vessel with the foil-covered vessels from the Aegean. However, it is more convincing to connect the decoration to south-eastern European manufacturing circles. Although exact analogies are lacking, the sheet buckle décor from the south-eastern Alpine area is stylistically and in terms of the manufacturing technique much closer to the Slovakian vessel than any Aegean metal decorated pottery.

In northern Europe, the picture is more complex. Mainly tin tacks were used to create metal ornamentation. The use of tin as material for the décor of non-metal vessels is a common element in northern Europe and the Aegean. But the decoration with tin tacks was used much earlier in northern Europe than tin foil decoration was used in Greece. Weapons with tin tacks in their wooden handles already date to the Late Neolithic and Early Bronze Age in north-western Europe (Butler/ 
van der Vaals 1966, fig. 25). This early appearance and the fact, that no other region uses tin tacks to create metal decoration on non-metal vessels suggests that the concept and the tacks are most probably locally developed and manufactured. The existence of indigenous nordic metal ornamentation using tacks made of pure tin indicates a regular tin import at least in the developed Period II. It is unlikely, that the tacks themselves were imported as finished products or that they were manufactured from a small charge of tin bars accidentally reaching the area. Since copper and bronze were regularly imported from Period I onwards (1800-1500 BC), it is only consequent to assume a regular tin trade in later periods. Once more it is remarkable that such technically demanding and at that time unique décor elements such as tin tacks and foils occur were no local tin deposits existed. This is the best indicator for intensive trade and involvement in wide-ranging raw material procurement networks.

Ornaments created with tin tacks are mostly described as star-shaped (e. g. Fischer U. 1954, 23), and the centre is in all cases placed in the middle of the vessel bottom. But the depiction of star-shaped ornaments with rays is in general not common in Bronze Age Europe. Pictograms, which are interpreted as stars, are depicted as dots, such as on the Nebra Sky disc (Meller 2010, 59-69). Only from the Carpathian basin are some depictions with rays known, which date roughly between 1600 and 1400 BC (David 2010, fig. 15; 19). On these pictograms the iconographic difference between the sun and the stars is unclear, often the number of rays determines whether it is the one or the other. However, this is an impression based on the modern variants of the star display. Today, stars can have up to twenty rays, which can not be assumed for the Bronze Age. Considering this, it is much more likely, that the sun is depicted on the bottom of the wooden vessels.

Through the tacks, a structurally similar décor to the buckle ornamentation is created, which is usually also characterized by outlines of ornaments. It never covers major parts of the vessel because there is once more no intention to conceal the surface entirely. Besides the colour, the tacks create a similar visual appearance as for example the small bronze buckles from the Laganiši cave vessel.

Some of the vessels are of brownish or dark colour, but black vessel surfaces are also very common among the finds, no matter if made of pottery or wood. The artificial blackening of the surface is a pan-European concept to ensure high contrast ornamentation.

The exclusive application of metal décor to drinking vessels in northern Europe is coherent with the use of the foil-covered vessels in Greece but not with other regions. Most of the tin lamellas are attached to jar- and amphora-like vessels, which function mostly as urns and are at least in their find contexts not related to drinking activities. However, the preferred position for metal decoration on the outer surfaces of the vessel's body, which are the rim, the belly, the handle and possibly the neck, is also a shared element on all tin decorated vessels no matter what technique of application. Overall, the nordic way of metal decoration on non-metal vessels is best described as a combination of local technical elements and widely spread contents of meaning.

\section{RESULTS AND INTERPRETATION}

The different regions in Europe have their traditions of manufacturing and aesthetic concepts of metal decoration of pottery. Bronze Age communities of northern Europe and the Iberian Peninsula preferred ornaments, which were formed entirely by the metallic appliques. This makes a vessel special and therefore it is important to place the metal décor on the widest point of the vessel's body, where it is most visible. In contrast, the metal décor in central and south-eastern Europe is mostly an additional element to the plastic decoration of the pottery surfaces, which is in many cases only applied at a later stage of the vessel's biography and was not included in its original aesthetic concept. Some of these metal appliques structurally supported and enhanced the clay ornaments; others completely disrespect it.

The vessels are usually of common regional shapes and the metal applications are exclusively used to create ornaments but do not cover large parts of the surface. Considering this, there is no reason to assume, that the metal decorated pottery or wooden vessels imitate metal or leather vessels. Although the metal buckles have a similar appearance as the bronze rivets applied on Italic helmets from the Early Iron Age, they do probably have a completely different meaning. The ceramic helmets are copies of bronze helmets with the same shape and the functional metal rivets are applied at the same parts on the model as they are at the metal helmets. In particular, the bronze buckles placed on the handles of ceramic cups and other drinking equipment speak against this. Their bronze counterparts on metal vessels are never placed at this part of the vessel because the handles are usually made of thick bronze sheets, were rivets are not needed to connect different parts of the vessel. The application of the buckles on non-metal vessels can therefore only be seen as pure décor, which is not 


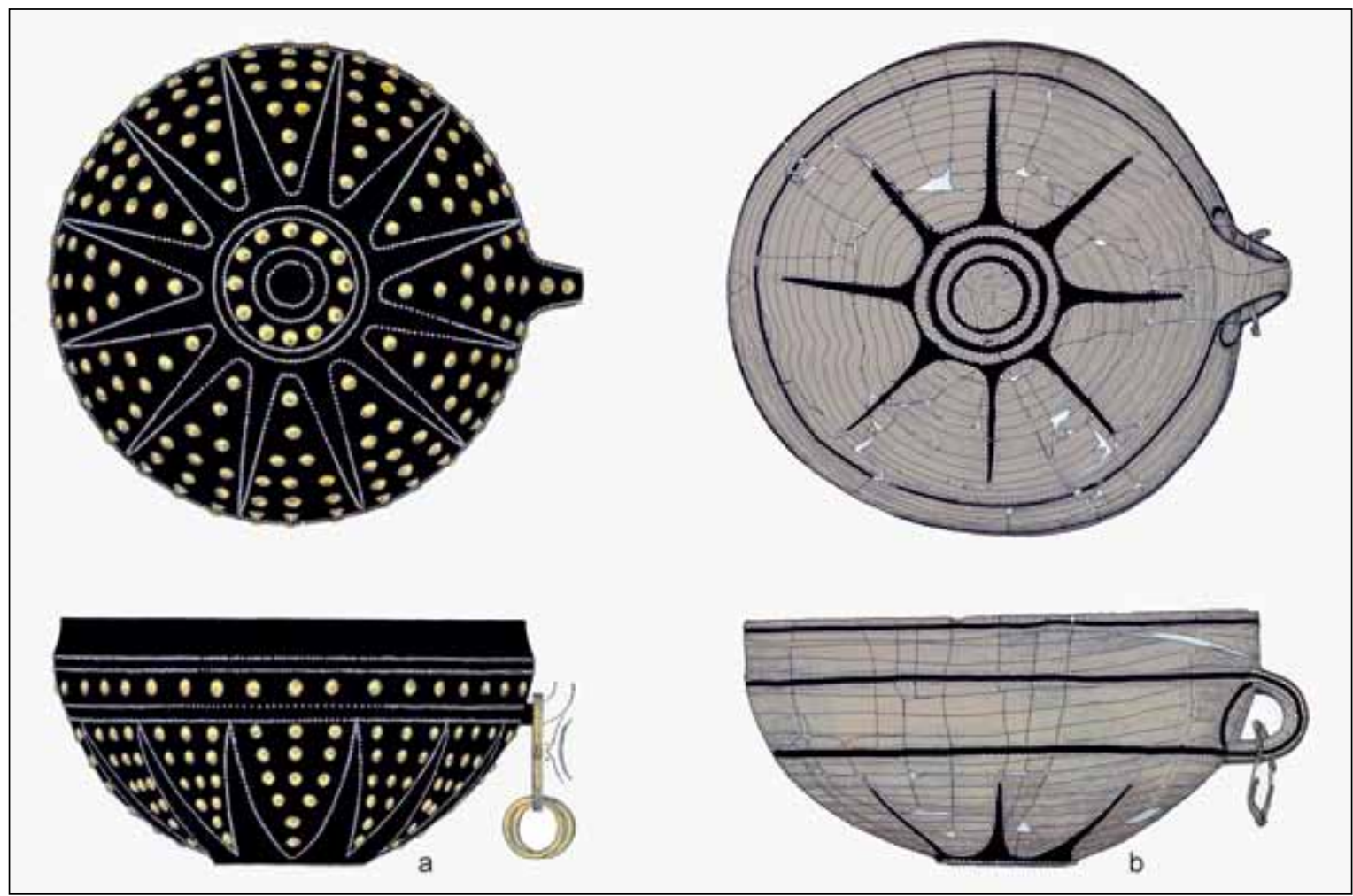

Fig. 4. Wooden vessels with blackened surfaces and applied tin tacks from Heerstedt and Barde (Store Hoj). a - Heerstedt (after Fischer U. 1954, fig. 5); b - Barde, Store Hoj (after Aner/Kersten 1995, pl. 8). Scale ca. 1:3.

imitating a metal model. North of Italy the bronze buckles are exclusively used to create ornaments on the vessel's bellies.

More important was the bi-chrome aesthetic of the vessels, which is exceptional for northern Europe, but a common element of south-eastern European artistic and communal expression. Bright incrustations, wool threads and paint on dark, polished surfaces appeared frequently from the beginning of the $2^{\text {nd }}$ millennium BC (Eibner 1967). The metal applications in the Carpathian Basin are only a part of extensive experimentation with colour in different contexts of meaning. The interplay of different materials combined at one object is well established in this region and points to a collaboration of at least two crafts persons to manufacture it. This kind of cross crafting, were the recipes for the inlays are often known and produced by one person but the carrier vessel was made by another (Sofaer/Roberts 2016, 482, 483). A similar collaboration can be assumed for the Aegean. The potter, who manufactured the vessel, might have also been the one who applied the metal foil, but he was not the one who manufactured the foil. How to produce a metal foil from such a rare raw material as tin was specialised knowledge, which only a metalsmith could have.
There can not be any doubt, that the application and use of metal foils to imitate metal vessels in the Aegean was an invention, which did not have any central or western European precursors. It might have been invented in the eastern Mediterranean or the Near East. This method was not adapted by central, western, or south-eastern European communities, although there is no reason why it may not have been known at least in neighbouring regions.

The roots of the decoration with metal tacks lay in the 'Northern Koiné' of Scandinavia and the north-western European shores. This means that the first appearance of the aesthetic concept to create ornaments with round metallic metal applications lies in northern Europe.

The decoration with bronze buckles needs to be seen as one decoration style, no matter if metal sheets on clay buckles or rivets were used to create it. Their visible appearance is similar and the chronological position of the finds indicates a first appearance of the buckle décor between 1300 and 1100 BC in the northern Carpathian Basin and the south-eastern Alps.

Nevertheless, the bronze buckle decoration also appears first in Scandinavia, because two wooden vessels from Norby und Heerstedt are not only decorated with tin tacks, but also with bronze buckles (Fig. 4). As mentioned above, all 
three date securely to the first quarter of the $14^{\text {th }}$ century BC. However, the decorations with bronze buckles may appear first in the north, but they were not manufactured for long. All the Nordic metal decorated finds date between 1500 and 1300 BC. This means that the southern, south-eastern and south-western regions of Europe started to create similar décor roughly one century later. In contrast to the north, the southern regions valued the metal decoration over a long period, and they developed and transformed it. In the Early Iron Age, this development culminated in the prime phase of the bronze buckle and lamella decoration in southern Europe.

\section{LITERATURE}

Aner/Kersten 1986 - E. Aner/K. Kersten: Die Funde der älteren Bronzezeit des Nordischen Kreises in Dänemark, Schleswig-Holstein und Niedersachsen. Band 8. Ribe Amt. Neumünster 1986.

Berezanskaja/Kločko 1998 - S. S. Berezanskaja/V. Kločko: Das Gräberfeld von Hordeevka. Archäologie in Eurasien 5. Rhaden/Westfalen 1998.

Brücken 2010-G. Brücken: Eine reiche urnenfelderzeitliche Doppelbestattung aus Bad Kreuznach. Mainzer archäologische Zeitschrift 9, 2010, 1-50.

Butler/van der Waals 1966 - J. J. Butler/J. D. van der Waals: Bell Beakers and early Metalworking in the Netherlands. Palaeohistoria 12, 1966, 41-139.

Carrasco/Pastor Muñoz/Pachón Romero 1985 - J. L. Carrasco Rus/M. Pastor Muñoz/J. A. Pachón Romero: Nuevos hallazgos en el conjunto arqueológico del Cerro de la Mora. La espada de lengua de carpa y la fíbula de codo del Cerro de la Miel (Moraleda de Zafayona, Granada). Cuadernos de Prehistoria y Arqueología de la Universidad de Granada 10, 1985, 265-334.

Cottier-Angeli/Duboscq/Harari 1997 - D. Cottier-Angeli/ B. Duboscq/M. Harari: La couleur de l'argent. Une enquête archéométrique autour des poteries à placage. Antike Kunst 40, 1997, 123-133.

David 2010 - W. David: Die Zeichen auf der Scheibe von Nebra und das altbronzezeitliche Symbolgut des Mitteldonau-Karpatenraumes. In: H. Meller/F. Bertemes (Hrsg.): Der Griff nach den Sternen. Wie Europas Eliten zu Macht und Reichtum kamen. Internationales Symposium in Halle (Saale) 16.-21. Februar 2005. Tagungen des Landesamtes für Vorgeschichte Halle (Saale) 5. Halle (Saale) 2010, 439-486.

Dehn 1942 - W. Dehn: Zwei Gefäße der Urnenfelderkultur mit Bronzezierart vom Rhein. Altschlesische Blätter. Nachrichtenblatt des Schlesischen Altertumsvereins und der Arbeitsgemeinschaft für Oberschlesische Ur- und Frühgeschichte 17, 1942, 123-126.

Dobiat 1980 - C. Dobiat: Das Hallstattzeitliche Gräberfeld von Kleinklein und seine Keramik. Schild von Steier. Beiheft 1. Graz 1980.

Dular 1982 - J. Dular: Halštatska keramika v Sloveniji. Dela Slovenska Akademija Znanosti in Umetnosti 23/12. Ljubljana 1982.

Eibner 1967 - C. Eibner: Zu einem metallfolienverzierten Beigefäß der jüngeren Urnenfelderbestattung aus Niederösterreich. Archaeologia Austriaca 42, 1967, 38-48.

Éluère/Raub 1991 - Ch. Éluère/Ch. J. Raub: Investigations on the gold coating technology of the great dish from Varna. In: J. P. Mohen (éd.): Découverte du metal. Paris 1991, 13-31.
Fischer U. 1954 - U. Fischer: Zu der bronzezeitlichen Holzschale von Heerstedt im Kreis Wesermunde. Jahrbuch des Römisch-Germanischen Zentralmuseums Mainz 1, 1954, 15-27.

Fischer C. 1993 - C. Fischer: Zinnnachweis auf Keramik der Spätbronzezeit. Archäologie der Schweiz 16, 1993, 17-24.

Furmánek 1970 - V. Furmánek: Lužické žárové pohřebiště v Beluši. Slovenská archeológia 18, 1970, 433-449.

Furmánek/Kruta 2002 - V. Furmánek/V. Kruta: L'età d'oro del Carpazi. Ceramiche e metalli dell'eta del Bronzo della Slovacchia 2300-800 a. C. Modena 2002.

García Huerta/Rodriguez 2000 - R. García Huerta/M. Rodriguez: La génesis del Mundo Ibérico en la submeseta sur. El tránsito del Bronce final - I Edad del Hierro en Alarcos. Cuadernos de Prehistoria y Arqueología de la Universidad de Granada 26, 2000, 47-68.

Gebhard 1997 - K. Gebhard: Eine zinnfolienverzierte urnenfelderzeitliche Scherbe aus dem hessischen Ried. Archäologisches Korrespondenzblatt 27, 1997, 237-244.

Gillis 1991 - C. Gillis: Tin in the Aegean Bronze Age. Hydra 8, 1991, 1-30.

Gillis 1994 - C. Gillis: Tin-covered Late Bronze Age vessels. Methods of application. In: F. Burragato/O. Grubessi/ L. Lazzarini (eds.): $1^{\text {st }}$ European Workshop on Archaeological Ceramics. Rom 1994, 26-34.

Gillis 1997 - C. Gillis: Tin-covered Late Bronze Age vessels. Analyses and social implication. In: C. Gillis/ C. Risberg/B. Sjoberg (eds.): Trade and Production in Premonetary Greece. Production and the Craftsman. Proceeding of the $4^{\text {th }}$ and $5^{\text {th }}$ International Workshop, Athens, 1994 and 1995. Jonsered 1997, 131-137.

Grubinger 1930 - M. Grubinger: Die Hügelgräber bei Wildon in Steiermark. In: J. Bayer (Hrsg.): Eiszeit und Urgeschichte. Jahrbuch für Erforschung des vorgeschichtlichen Menschen und seines Zeitalters 71. Leipzig 1930, 114-123.

Hencken 1968 - H. Hencken: Tarquinia, Villanovans and early Etruscans. Cambridge 1968.

Hugues 1969 - C. Hugues: Céramique à cabochons de bronze du Gard. Revue Archéologique de Narbonnaise 2, 1969, 207-210.

Ivanov 1988 - I. Ivanov: Das Gräberfeld von Varna - Katalog. In: A. Fol/J. Lichardus (Hrsg.): Macht, Herrschaft und Gold. Das Gräberfeld von Varna (Bulgarien) und die Anfänge einer neuen europäischen Zivilisation. Saarbrücken 1988.

Kossack 1995 - G. Kossack: Mitteleuropa zwischen dem 13. und 8. Jahrhundert v. Chr. Geb. Geschichte, Stand und Probleme der Urnenfelderforschung. In: M. zu Erbach/H. Fokkens/B. Gediga (Hrsg.): Beiträge zur Urnenfelderzeit nördlich und südlich der Alpen. Ergebnisse 
eines Kolloquiums. Monographien des Römisch-Germanischen Zentralmuseums 35. Mainz 1995, 1-64.

Laffineur 1974 - R. Laffineur: L'incrustation à l'epoque Mycénienne. L'Antiquité Classique 43, 1974, 5-37.

León Pastor 2002-2003 - E. León Pastor: La secuencia cultural de la Corduba prerromana a través de sus complejos cerámicos: Las Fases III y IV del corte 1 de la I. A. U. practicada en el teatro de la Axerquía. Anales de Arqueología Cordobesa 13-14, 2002-2003, 29-66.

Leskov 1981 - A. M. Leskov: Jung- und spätbronzezeitliche Depotfunde im nördlichen Schwarzmeergebiet I (Depots mit einheimischen Formen). PBF XX/5. München 1981.

Lochner 1986 - M. Lochner: Ein urnenfelderzeitliches Keramikdepot aus Oberravelsbach, Niederösterreich. Archaeologia Austriaca 70, 1986, 295-316.

Lucas Pellicer 1995 - R. Lucas Pellicer: Cerámicas con apliques de metal. Boletín de la Asociación Espańola de Amigos de la Arqueologia 35, 1995, 107-122.

Meller 2010 - H. Meller: Nebra. Vom Logos zum Mythos - Biographie eines Himmelsbildes. In: H. Meller/ F. Bertemes (Hrsg.): Der Griffnach den Sternen. Wie Europas Eliten zu Macht und Reichtum kamen. Internationales Symposium in Halle (Saale) 16.-21. Februar 2005. Halle (Saale) 2010, 23-73.

Mihovilić 2008-K. Mihovilić: Vessel decorated with Bronze Appliqués, In: D. Komšo (ed.): Peina Laganiši. Mjesto života $i$ smrti = Laganiši cave. A place of life and death. Pula 2008, 16-17.

Molina 1983 - F. Molina: Prehistoria de Granada. Granada 1983.

Müller-Karpe 1957 - H. Müller-Karpe: Münchener Urnenfelder. Ein Katalog. Kallmünz/Opf. 1957.

Noll 1991 - W. Noll: Alte Keramiken und ihre Pigmente. Studien zu Material und Technologie. Stuttgart 1991.

Ožd’áni 1977 - O. Oždáni: Amfora podolskej kultúry s kovovou výzdobou z Brhloviec. Slovenská archeológia 25, 1977, 463-472.

Manuscript accepted 6. 7. 2020

Translated by Bianka Nessel

Súhrn preložil Martin Neumann
Pantelidou 1971 - M. Pantelidou: LH III A1 vases covered with tin foil. Archaiologika Analekta ex Athénon 4, 1971, 433-438.

Parzinger 2006 - H. Parzinger: Die frühen Völker Eurasiens. Vom Neolithikum bis zum Mittelalter. München 2006.

Paulík 1962 - J. Paulík: Das Velatice-Baierdorfer Hügelgrab in Očkov. Slovenská archeológia 10, 1962, 5-96.

Randsborg/Christensen 2006 - K. Randsborg/K. Christensen: Bronze Age oak-coffin graves. Archaeology and dendrodating. Acta Archaeologica (København) 77. Supplementum 7. København 2006.

Rieth 1939-1940 - A. Rieth: Zur Technik antiker und prähistorischer Kunst. Das Holzdrechseln. Jahrbuch für prähistorische und ethnographische Kunst 13-14, 1939-1940, 85-107.

Sofaer/Roberts 2016 - J. Sofaer/S. Roberts: Technical innovation and practice in Eneolithic and Bronze Age Encrusted ceramics in the Carpathian Basin, Middle and Lower Danube. Archäologisches Korrespondenzblatt 46, 2016, 479-498.

Stjernquist 1958 - B. Stjernquist: Ornementation métallique sur vases d'argile. Meddelanden från Lunds Universitets Historiska Museum 1958, 107-169.

Szombathy 1903-J.Szombathy: Die Tumuli von Gemeinlebarn. Mitteilungen der Prähistorischen Kommission der Österreichischen Akademie der Wissenschaften in Wien 1, 1903, 49-77.

Torres Ortiz 2001 - M. Torres Ortiz: La cerámica a mano con decoración de botones de bronce: una aportación al estudio de la alfarería tartésica del Bronce Final. SPAL. Revista de prehistoria y arqueología de la Universidad de Sevilla 10, 2001, 275-281.

Vancugov 1996 - V. P. Vancugov: Das Ende der Bronzezeit im nördlichen Schwarzmeergebiet - Die Belozerka-Kultur. Eurasia antiqua 2, 1996, 287-309.

Zipp 2010 - K. Zipp: Anthropologische Untersuchungen der Skelettfunde aus einem urnenfelderzeitlichen Körpergrab in Bad Kreuznach. Mainzer archäologische Zeitschrift 9, 2010, 51-54.

Dr. phil. Bianka Nessel Institute for Pre- and Protohistory Johannes-Gutenberg University Mainz Schillerstrasse 11 D - 55116 Mainz bnessel@uni-mainz.de 


\title{
Kovové aplikácie $\mathrm{v}$ dobe bronzovej $\mathrm{v}$ Európe - pátranie po význame pripináčikov, puklíc a lamiel
}

\author{
Bi a n k N e s sel
}

\author{
SÚHRN
}

Príspevok do tohto zborníka, ktorý je venovaný prof. Jozefovi Bátorovi k narodeninám, sa zaoberá distribúciou a významom rôznych druhov výzdoby kovovými aplikáciami na nádobách zhotovených z keramiky a dreva, a to so špeciálnym ohladom na výzdobu nitmi zhotovených z okrúhlych plátov bronzu.

Je zrejmé, že pre aplikáciu kovu na rôzne druhy keramických nádob boli používané rôzne techniky a že rôzne typy kovovej výzdoby boli naviazané na konkrétne regióny. Domnievam sa, že spoločnosti doby bronzovej si formou kovovej výzdoby na keramike a drevených nádobách vytvárali vlastné tradície a estetické koncepty. V severnej a juhozápadnej Európe bola preferovaná výzdoba vytvorená výhradne z kovových aplikácií, kým v strednej a juhovýchodnej Európe bola kovová výzdoba len doplnkom k plastickej výzdobe keramických nádob.
Je možné predpokladat, že okrúhle kovové puklice na nekovových nádobách neslúžili výhradne ako dekorácia a nemala za ciel' imitovat' kovové nádoby. Naopak sa zdá, že kovové pliešky rôznych tvarov, ktoré boli nájdené vo viacerých oblastiach, mali odlišný význam a s istotou môžu byt' spájané s imitáciou kovových nádob.

Výzdoba kovovými puklicami sa pravdepodobne prvýkrát objavila v severnej Európe, kde, ako sa zdá, bola využívaná počas dvoch storočí medzi rokmi 1500 a 1300 pred n. 1. V južnej, juhovýchodnej a juhozápadnej Európe začali miestne spoločnosti vytvárat’ podobnú výzdobu až o jedno storočie neskôr. Vd’aka svojej oblube tu však pretrvala ovel’a dlhší čas. V týchto regiónoch bola táto výzdoba aj d’alej rozvíjaná a transformovaná, čo v južnej Európe na počiatku doby železnej viedlo k jej úplne novej významovej náplni. 
